\title{
Detection of Ampicillin Resistance Encoding Gene of Escherichia coli from Chickens in Bandung and Purwakarta
}

\author{
Kuntum Khoirani ${ }^{*}$, Agustin Indrawati ${ }^{2}$, Surachmi Setiyaningsih ${ }^{3}$ \\ 'Postgraduate Student, Department of Animal Disease and Veterinary Health, Bogor Agricultural \\ University, Jl. Agatis, Kampus IPB Darmaga Bogor 16680, Indonesia \\ ${ }^{2}$ Department of Animal Disease and Veterinary Health, Bogor Agricultural University. Jl. Agatis, \\ Kampus IPB Darmaga Bogor 16680, Indonesia \\ *Corresponding author: Kuntum Khoirani (e-mail: kuntumkhoirani22@gmail.com)
}

\begin{abstract}
The purpose of this study was to test the resistance and to detect antibiotic resistance encoding gene in E. coli bacteria from chickens in Bandung and Purwakarta livestock. 18 E. coli isolates were tested for antibiotics resistance using the disk diffusion method. Isolates that were categorized as resistance and intermediate to antibiotics, then polymerase chain reaction was utilized to detect the resistance coding gene. The test results showed that all $E$. coli isolates from chickens in Bandung and Purwakarta were resistance to ampicillin (100\%). E. coli isolates were still sensitive to chloramphenicol (11.1\%) and gentamicin (22.2\%). The gene encoding for ampC resistance were found $77.7 \%$. Sensitivity test results and detection of resistance coding gene showed that almost all isolates were resistance to ampicillin antibiotics and $E$. coli isolates were still sensitive to chlorampenicol and gentamicin.
\end{abstract}

Key words: antibiotics, E. coli, genes, resistance

Copyright $\odot 2019$ JRVI. All rights reserved.

\section{Introduction}

Escherichia coli in chickens is naturally a commensal and harmless bacteria found in the gastrointestinal tract, and there are some that are disease-causing pathogens and are used as indicators to monitor the incidence of antibiotic resistance in livestock as well as products of animal origin (Ajayi et al. 2011 ). Recently, pathogenic E. coli bacteria are increasingly found in the field that cause diseases such as cholibasilosis, which is very detrimental to the world of poultry.

The threat to antibiotic resistance has become an important concern in the field of public health. According to Laxminarayan et al. (2013), due to antibiotic-resistant bacterial infections each year, nearly 58391 infants in India and estimated 25000 ones in Europe die. The use of antibiotics on farms usually aims to treat disease or therapy, to prevent the occurrence of disease by inhibiting the growth of pathogenic microorganisms, and mixing light-dose antibiotics in feed is done in order to increase feed efficiency (Barton 2000). The use of antibiotic doses continues to be the cause of the emergence of resistance in bacteria, and because of its resistance to antibiotics, it can cause the least selection of drugs for the treatment of infections, then this 
affects on treatment failure and requires repeated use of antibiotics with various classes of antibiotics.

E. coli is known to show resistance to several types of antibiotics. Bacteria that naturally have antibiotic resistant genes can act as the reservoir by transferring these genes to other bacteria (Ibrahim et al. 2016). The nature of resistance can be transferred through a mechanism called horizontal gene transfer to other bacteria including pathogenic bacteria, and it ultimately can affect on human health.

\section{Materials and Methods}

\section{Research Sample}

Samples were in the form of cloaca swabs, litters, and drinking water taken in aspiration from breeder and layer chicken farms in Bandung and Purwakarta districts. Samples were carried with ice flasks for laboratory analysis at the Laboratory of the Department of Veterinary Sciences and Veterinary Public Health, Faculty of Veterinary Health, Bogor Agricultural University. Based on the estimated observation, prevalence of disease incidence in the amount of 3.7\% with a $5 \%$ degree of error, the number of samples needed for testing with a $95 \%$ confidence level is minimum in the amount of 57 samples (Martin et al., 1987).

\section{Isolation and Identification Of Escherichia Coli}

Samples were plated in eosin methyene blue agar (EMBA) media with spread method. Culture was incubated at $37{ }^{\circ} \mathrm{C}$ for approximately $18-24$ hours. Identified as E.coli, further confirmed by Gram staining procedure and biochemical tests. Furthermore, they were tested by motile-indole sulfide (SIM) test, Methyl Red (MR) test, Voges-Proskauer test (VP), citrate test, and incubated at $37^{\circ} \mathrm{C}$ for 24 hours, after media color changes were observed (SNI 2008).

\section{Antibiotic Sensitivity Test}

The antibiotic sensitivity test was carried out based on the disk diffusion method according to the Clinical and Laboratory Institute (CLSI) guidelines (CLSI 2018). Each of 2-5 groups of $E$. coli isolates from each sample was suspended in a physiological $\mathrm{NaCl}$ solution. Turbidity of bacterial suspension was diluted to reach Mcfarland standard in the amount of 0.5 or equivalent to 1.5 $\times 108 \mathrm{CFU} / \mathrm{ml}$, then in the amount of $1 \mathrm{~mL}$ of each bacterial suspension was poured and then flattened on Mueller-Hinton agar in a petri dish, using sterile cotton swab. Diffusion disks that contain antibiotics were placed on top of the Mueller-Hinton using sterile tweezers with the same distance, and then incubated at $37^{\circ} \mathrm{C}$ for $18-24$ hours, and measurement of antibiotic inhibition zones was done based on predetermined standards. Standards in the form of categories included susceptible (S), susceptible dose dependent (SDD), intermediate (I), and resistant $(R)$. The categories were determined by the range of diameter of the antibiotic inhibitory zone which was formed on Muller-Hilton agar based on the Cllinical and Laboratory standards Institute guidelines (CLSI 2018).

\section{Detection of ampC Antibiotic Resistance Encoding Gene}

Extraction of $E$. coliDNA that was resistant to antibiotics was carried out by the boiling method. The presence of antibiotic resistance coding genes was detected by genes primer of ampC (ampicillin resistent gene) using single PCR. Primer sequences of the ampC gene were 5'AATCGCTTTTCTACGGTCTC-3 ' for forward sequence and 5'-GGGCAGCAAATCTCGACCAA3' for reverse sequence (Brinas et.al. 2002) with amplicon target in the number of $191 \mathrm{bp}$. The amplification process used KAPA2G Fast Readymix PCR Kit®. The total volume of PCR 
reactions was $25 \mu \mathrm{L}$, consisting of $1 \mu \mathrm{L}$ DNA template, $12.5 \mu \mathrm{L}$ mastermix, $1.25 \mu \mathrm{L}$ forward primer $10 \mu \mathrm{M}, 1.25 \mu \mathrm{L}$ reverse primer $10 \mu \mathrm{M}$, and $9 \mu \mathrm{L} \mathrm{H} 2 \mathrm{O}$. The amplification process began with predenaturation at $95^{\circ} \mathrm{C}$ for 3 minutes, then 35 cycles of the amplification process with denaturation temperature at $95^{\circ} \mathrm{C}$ for 30 seconds, annealing at $58{ }^{\circ} \mathrm{C}$, extension at $72{ }^{\circ} \mathrm{C}$ for 1 minute and at the end the amplification was the final extension at $75^{\circ} \mathrm{C}$ for 5 minutes. The amplified samples were visualized by electrophoresis using $1 \%$ agarose gel and stained using ethidium bromide $0.5 \mu \mathrm{g} / \mathrm{mL}$. A molecular weight marker with 100 bp (VC 100 bp Plus DNA Ladder Vivantis, Selangor, Malaysia) was used as a Standard size.

\section{Results and Discussions}

\section{Isolation and Identification of Escherichia coli}

The results of $E$. coli growth from 57 samples on the EMBA media showed as many as 18 metallic green colonies with black spots in the middle of the colony. The Gram staining procedure showed rod-shaped cell in Gram staining. The confirmation of E. coli colonies with the IMVIC test showed positive results on the indole test and methyl red test, while the negative results in the voges proskauer test and citrat test. With the results of the biochemical test, the growing colonies were confirmed as colonies of E. coli bacteria. (Soemarno 2000) states the groups that include fecal bacteria show positive results for the indole and methyl red test whereas bacteria that show positive results on the voges proskauer test and citrat test are included in the non-fecal group.

According to OIE (2013), E. coli as a commensal bacterium is a bacterium that is commonly used as an indicator in surveillance programs and monitoring antibiotic resistance. $E$. coli can act as a reservoir of genes that have been resistant to antibiotics. This gene can be transferred to other pathogenic bacteria. $E$. coli is chosen because it is an indicator of Gram negative bacteria that is often found in animal feces and is related to treatment in humans. Furthermore, it frequently contains plasmids that can move between enteric bacteria. The presence of commensal $E$. coli in livestock gut acts as a reservoir of resistant genes that can move horizontally to pathogenic E. coli and other bacteria in the food chain.

\section{Antibiotic Sensitivity Test}

Antibiotic sensitivity testing of the $18 \mathrm{E}$. coli isolates showed that all isolates are resistance to ampicillin (100\%), $11.1 \%$ resistant to chloramphenicol, and $22.2 \%$ resistant to gentamicin (Table 1).

\begin{tabular}{ccccc} 
Table 1: Results of antibiotic sensitivity test for E. coli bacteria \\
\hline Group & Antibiotic & Resistant & Intermediate & Susceptible \\
\hline B-laktam & Ampisilin & $100 \%$ & $0 \%$ & $0 \%$ \\
Klorampenicol & Klorampenicol & $11.1 \%$ & $66.6 \%$ & $22.2 \%$ \\
Aminoglycoside & Gentamicin & $22.2 \%$ & $72.2 \%$ & $5.5 . \%$ \\
\hline
\end{tabular}

The results of the antibiotic sensitivity test showed $100 \%$ resistance to ampicillin, followed by $11.1 \%$ resistant to chloramphenicol, and $22.2 \%$ resistant to gentamicin (Table 1 ). The used of antibiotics as Antibiotic Growth Promoter (ACP) mixed in feed or drinking water was thought to be one of the causes of the high incidence of resistance to ampicillin. Addition of AGP plays a role in the emergence of this resistance event. The addition causes normal flora and pathogenic bacteria to be eliminated, stock farmers did this probably to anticipate the losses caused by bacterial diseases declines, then livestock production is going to increase. The antibiotic concentration added to animal feed in low dose around 2.5-12.5 mg / kg (ppm) was 
proven to be able to spur the resistance of pathogenic bacteria and commensal bacteria in the digestive tract (Noor and Poeloengan 2005).

Prohibition of Hormones and AGP use written in Law No. 18 in 2009 concerning Animal Husbandry and Animal Health which is then clarified by Minister of Agriculture Regulation No. 14/Permentan/ PK.350 /5/2017 about Classification of Antibiotic Animal Medicine as AGP. This regulation needs to be followed by routine surveillance and monitoring. The ease of obtaining antibiotics and the low price of antibiotics makes it difficult to control antibiotic use on farms in Indonesia (Amalia and Adisasmito, 2017). Detection of ampC Antibiotic Resistance Encoding Gene.

Molecular detection of resistance encoding genes was conducted on $E$. coli isolates with antibiotic resistance which categorized as intermediate by using PCR. Detection of the ampC gene showed positive results in $14 \mathrm{E}$. coli isolates (77.7\%) that were resistant to ampicillin with a 191 bp amplicon (Figure 1).

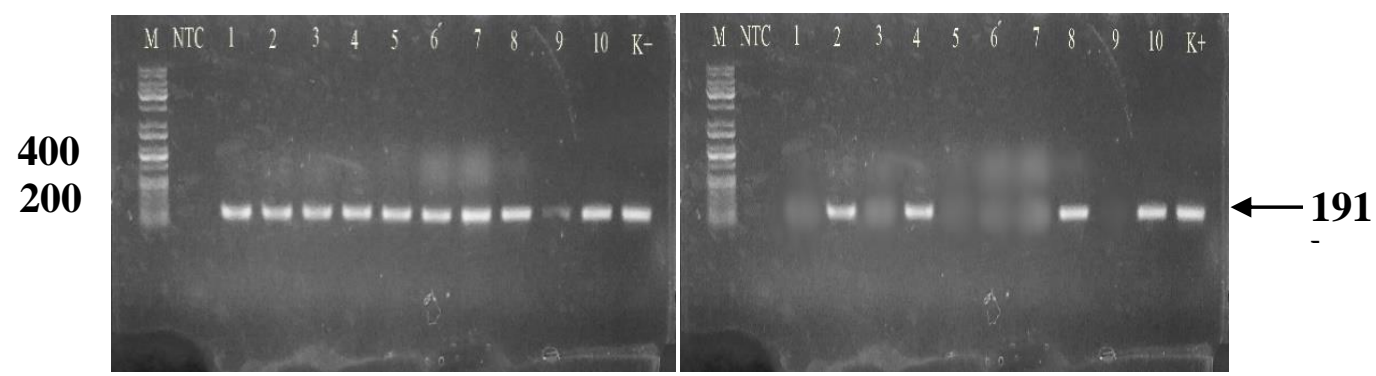

Figure 2 Amplification of genes ampC (191 bp) encoding resistance to ampicillin in E. coli. A total of 14 isolates showed positive results for ampC and 4 isolates showed negative results against ampC. M: 100 bp marker; NTC: non template control.

The presence of the ampC gene in bacteria cells is related to resistance to ampicillin. Many Enterobacteriaceae expressing ampC have a low affinity, but they are induced in response to beta-lactam exposure. The induction mechanism is complex. Interference with biosynthesis of murein by beta-lactam agent causes accumulation of $\mathrm{N}$-acetylglucosamine-1,6-anhydro- $\mathrm{N}$ acetylmuramic acid oligopeptide. The $\mathrm{N}$-acetylglucosamine group is removed to produce a series of 1,6-anhydro-N-acetylmuramic acid tri-, tetra, and pentapeptides. These oligopeptides compete with UDP-N-acetylmuramic oligopeptides for binding sites in ampR, those which are parts of the LysR regulator. Transfer of UDP-N-acetylmuramic acid peptides indicates a conformational change in ampR, which activates the transcription of ampC (Jacoby 2009).

\section{Conclusion}

Eighteen $E$. coli isolates from cloacal swabs, litters, and drinking water in chicken farms in Bandung and Purwakarta. All E. coli isolates this present study revealed a high rate of resistance AMP. In addition, $11.1 \%$ of isolates are resistant to chloramphenicol, and $22.2 \%$ of isolates are resistance to gentamicin. Resistance encoding gene that can be detected include ampC in the amount of $77.7 \%$. Further studies need to be conducted to detect antibiotics encoding genes other than $a m p C$ so that the pattern of spread can be identified.

\section{Acknowledgments}

The authors would like to thank Drh. Maya Sofa from Terpadu Laboratories for help with Microbiology Laboratory facilities. This study was supported by funding of Insentif Riset Sistem Inovasi Nasional (ISINAS) 2018 chaired by Prof. Dr. Drh. Fachriyan Hasmi Pasaribu. 


\section{Refferences}

Ajayi AO, Oluyege AO, Olowe OA, Famurewa O. 2011. Antibiotik resistance among commensal Escherichia coli isolated from faeces of cattle in Ado-Ekiti, Nigeria. J Anim Vet Adv. 10(2):174-175.

Amalia Z, Adisasmito W. 2017. Analysis of Policy making Factors on The Prohibition of Hormones and Antibiotcs Use for Feed as a public health Protection. JIHPA. 2(@): 14-19.

Barton MD. 2000. Antibiotic use in animal feed and its impact on human health. Nuutr Res Rev. 13(2):279-299.

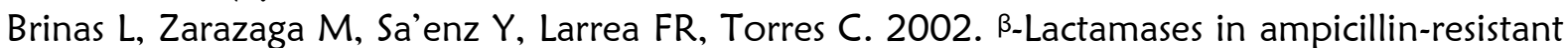
Escherchia coli isolates from foods, humans, and healthy animals. Antimicrob Agents Chemother. 46(10):3156-3163.

[CLSI] Clinical and Laboratory Standards Institute. 2018. Perfomance Standards for Antimicrobial Susceptibility Testing $28^{\text {th }}$ ed. CLSI Suplement M100. Wayne, PA : Clinical and Laboratory Standars Institute ; 2018.

Ibrahim DR, Dodd CER, Stekel DJ, Ramsden SJ, Hobman JL. 2016. Multidrug resistant, Extended Spectrum $\beta$-Lactamase (ESBL)-producing Escherichia coli from a dairy farm. FEMS Microbiol Ecol. 92(4):1-13.

Jacoby GA. 2009. AmpC B-Lactamases. Clinical Microbiology Reviews, Jan. 2009, p. 161-182

Laxminarayan R, Duse A, Wattal C, Zaidi AKM, Wertheim HFL, Sumradit N, Vlieghe E, Hara GL, Gould IM, Goossens H, Greko C, So AD, Bigdeli M, Tomson G, Woodhouse W, Ombaka E, Peralta AQ, Qamar FN, Mir F, Kariuki S, Bhutta ZA, Coates A, Bergstrom R, Wright GD, Brown ED, Cars O. 2013. Antibiotic resistance- The need for global solutions. Lancet infect. Di. 13: 1057-1098

Martin, S.W., Week, A.H. and Willenberg, P., 1987. Veterinary Epidemiology Principles and Methods, 1st ed. lowa State University Press, Ames: 22-175.

Noor SM, Poeloengan M. 2005. Pemakaian antibiotik pada ternak dan dampaknya pada kesehatan manusia. Prosiding lokakarya nasional keamanan pangan produk peternakan. Bogor (ID): Puslitbang Peternakan. 18-22.

[OIE] Office Internationale des Epizooties. 2013. Harmonisation of national antimicrobial resistance surveillance and monitoring programmes chapter 6.7. [www.oie.int/fileadmin/Home/eng/Health_standards/tahc/2010/en_chaptire_1.6.7.htm. ]

[SNI]. Standar Nasional Indonesia. 2008. Metode Pengujian Cemaran Mikroba dalam daging, telur, dan Susu serta Hasil Olahannya. SNI 2897. ICS 67.050. Jakarta, Indonesia (ID): SNI.

Soemarno. 2000. Isolasi dan identifikasi bacteri klinik. Yogyakarta. Akademi Analis Kesehatan Yogyakarta Departemen Kesehatan RI. 